\section{An International Society of Addiction Medicine (ISAM): The Time Is Now!}

\section{N. el-Guebaly, President, ISAM}

Over the last few years, the academic and practice developments in addiction medicine have resulted in the creation of a number of national medical societies to further promote the field. This creative evolution over some 20 years resulted in an American Society of Addiction Medicine soon followed by the foundation of Canadian, Portuguese and Panamanian societies and now, the newest welcomed addition, of a German Society. An international organization fostering communication between the various individuals and groups involved while respecting the national initiatives was, for many of us, the natural next step. This year, such a society has been formally constituted at a meeting held in Palm Springs, Calif., the site of the Betty Ford Center, on April 24-26, 1999. One hundred physicians from 31 countries drafted a mission statement and formed the first governing Board of 17 members from: Argentina, Brazil, Canada, China, Germany, Iceland, India, Israel, Italy, Panama, Portugal, United Kingdom and the United States. The terms of office are 3 years. Our current mailing list includes 225 physicians from 62 countries. All continents are represented.

ISAM is starting as a membership-based organization. The possible addition of an organization-based membership will be examined at a later date. It is an international society of physicians for whom addiction is a preventable and treatable disease. There is growing empirical evidence that physicians worldwide have a major role in the management of addiction and that the field of addiction medicine is becoming an essential medical specialty.

The creative debate at the meeting included a concern from some members that the disease concept may be perceived as too narrow but the majority of attendants felt that the model validated the role of the physician best. The multidisciplinary field of addiction medicine was construed as similar to the field of oncology. A major component of ISAM's activities is through a network of 8 committees. Joint efforts in these committees will encompass promotion of the physician's role: medical education, communication and international consensus, treatment, research, policy, treatment of impaired professionals, prevention, ethical considerations, and multidisciplinary collaboration. Physicians recognize the sociocultural and other aspects of addiction and welcome the opportunity to collaborate with other nonmedical professionals in the field. The second formal meeting of ISAM is being organized in Israel, and the target date is November 5-9, 2000.

An outlook on future tasks: ISAM is very much part of the general trend toward globalization. Aside from providing a supportive, educational network to physicians in the field through electronic communication and meetings, we will strive to develop consensual position papers on a number of issues relevant to the practice of physicians. We plan annual or biannual general meetings but also regional meetings to discuss these issues. We also wish to rely on existing conferences either as a cosponsor or program participant. The dream is to build a strong, united, informed medical voice speaking on behalf of our patients as we participate in the prevention and management of addictions worldwide in full collaboration with other disciplines. Organizations such as the United Nations, the World Health Organization, the European Community and the Organization of American States ought to benefit from the informal and coordinated input of dedicated physicians.

If you are interested in joining, please contact the ISAM office at the following address for a membership application form:

Marilyn D’Orozio, Secretary, ISAM Office

Addiction Centre, Foothills Hospital, 1403-29 Street NW

Calgary AB T2N 2T9 (Canada)

Tel./Fax +1 403670 2029, E-Mail nady.el-guebaly@crha-health.ab.ca

\section{KARGER}

(c) 1999 S. Karger AG, Basel

Fax + 41613061234 E-Mail karger@karger.ch www.karger.com
Accessible online at: www. karger.com/journals/ear 